\title{
The Role of a Single Nucleotide Polymorphism of the Matrix Metalloproteinase-1 Gene Promoter Region in Invasion and Prognosis of Meningiomas
}

\author{
Menenjiyomlu Hastalarda Matriks Metalloproteinaz-1 Geni Promotor \\ Bölgesi Tek Nükleotid Polimorfizminin Invazyon ve Prognozdaki Roliu
}

Mustafa EFENDIOGLU ${ }^{1}$, Recep BASARAN ${ }^{1}$, Omer Faruk BAYRAK ${ }^{2}$, Nejat ISIK ${ }^{3}$, Tuncay KANER ${ }^{3}$, Fikrettin SAHIN ${ }^{2}$, Bulent GUCLU ${ }^{1}$, Ilhan ELMACI ${ }^{4}$

${ }_{1}^{1}$ Ministry of Health, Dr. Lutfi Kirdar Kartal Training and Research Hospital, Neurosurgery Clinic, Istanbul, Turkey

${ }^{2}$ Yeditepe University, School of Genetics and Bioengineering, Istanbul, Turkey

${ }^{3}$ Istanbul Medeniyet University, Goztepe Training and Research Hospital, Department of Neurosurgery, Istanbul, Turkey

${ }^{4}$ Medipol University, School of Medicine Hospital, Department of Neurosurgery, Istanbul, Turkey

Corresponding Author: Bulent GUCLU / E-mail: guclubulent@hotmail.com

\section{ABSTRACT}

AIM:The matrix metalloproteinase (MMP) enzyme family has been shown to be active in tumorigenesis and tumor progression. In this study, we analyzed the prevalence of a guanine insertion in the MMP-1 gene promoter region in meningiomas and its effect on invasion and prognosis.

MATERIAL and METHODS: The study was performed with 33 meningioma patients. We also included 33 healthy patients in the study as a control group. The promoter area was amplified by polymerase chain reaction (PCR) following DNA isolation. The polymorphism was detected by restriction fragment length polymorphism (RFLP).

RESULTS: According to the WHO classification of meningiomas, $87.9 \%$ of the affected patients were grade 1 , and $12.1 \%$ were grade 2 . In total, $72.7 \%$ of the meningioma patients $(n=24)$ had at least one copy of the insertion ( $2 \mathrm{G} / 1 \mathrm{G}$ or $2 \mathrm{G} / 2 \mathrm{G}$ genotypes) and $27.3 \%$ ( $n=9)$ did not $(1 \mathrm{G} / 1 \mathrm{G})$. There was no significant difference between the meningioma and control groups according to genotype distribution.

CONCLUSION: In this study, the polymorphism in the matrix metalloproteinase-1 gene promoter region did not have an effect on the initiation, growth and progression of meningioma.

KEYWORDS: Meningioma, Single nucleotide polymorphism, SNP, MMP-1, Interstitial collagenase, Matrix metalloproteinase

öz

AMAÇ: Matriks metalloproteinaz (MMP) enzim ailesinin tümör oluşumu ve progresyonunda etkili olduğu gösterilmiştir. Bu çalışmada menenjiyomlarda matriks metalloproteinaz-1 geni promotor bölgesine guanin insersiyonunun prevalansı ve bunun invazyona ve prognoza etkisi araştırıldı.

YÖNTEM ve GEREÇLER: Çalışma 33 tane menenjiyomlu hasta ile yapıldı. Aynı zamanda 33 tane sağlıklı kişi de çalışmaya kontrol grubu olarak dahil edildi. DNA izolasyonundan sonra promotor bölge polimeraz zincir reaksiyonu ile çoğaltıldı. Polimorfizm, restriksiyon fragman uzunluk polimorfizmi ile tesbit edildi.

BULGULAR: Dünya Sağlık Örgütü (DSÖ) sınıflamasına göre hastaların \%87,9'unda derece I, \%12,1'inde derece II menenjiyoma saptandı. Menenjiyomlu hastaların \%72,7'si $(n=24)$ en az bir tane guanin insersiyonuna sahipti (2G/1G or 2G/2G genotipleri), ve \%27,3' ü ( $n=9)$ sahip değildi (1G/1G). Genotip dağılımına göre menenjiyomlarla kontrol grubu arasında bir fark yoktu.

SONUÇ:Bu çalışmada menenjiyomlarda matriks metalloproteinaz-1 geni promotor bölgesindeki polimorfizmin, menenjiyomların başlamasınabüyümesine ve ilerlemesine etki etmediği izlenmiştir.

ANAHTAR SÖZCÜKLER: Menenjiyom, Tek nükleotid polimorfizmi, SNP, MMP-1, Matriks metalloproteinaz, İnterstisyel kollajenaz

\section{INTRODUCTION}

Meningiomas are mostly benign, slowly developing, extra axial tumors that arise from arachnoid cap cells and their progression is highly difficult to anticipate (18). Although some subtypes of meningiomas are histopathologically benign, they may still exhibit aggressive behavior.
The matrix metalloproteinase (MMP) enzyme family is active in invasion and progression of many diseases by their degradation of the extracellular matrix $(24,28)$. Matrix metalloproteinase-1 (MMP-1), also known as collagenase-1, is a zinc-dependent endopeptidase $(17,19,33)$ that is responsible for the breakdown of the extracellular matrix. Studies have shown 
that the amount of MMP-1 in a tumor is closely related to the tumor grade and invasiveness (13). MMP-1 gene expression is controlled by activator protein-1 (AP-1) bound to regions in the MMP-1 promoter and mitogen-activated kinase through polyomavirus-enhancing activity-3 (PEA-3/ETS) (22, 31). A new ETS-binding site is created by a guanine insertion in the MMP-1 gene promoter region at bp position 1607, thus enhancing the transcriptional activity of the MMP-1 gene. The presence of this guanine insertion is also correlated with the incidence and progression of several cancers (21). Studies of brain tumors suggest that there is a close relationship between the insertion in the MMP-1 promoter region and an increase in tumor grade in astrocytoma, glioblastoma multiforme and pituitary adenoma cases $(1,10,11,13,31)$.

This aim of this study was to detect a guanine insertion in the MMP-1 gene promoter region in meningiomas and to show the effect of this polymorphism on the frequency and invasion of meningioma tumors.

\section{MATERIAL and METHODS}

This study was conducted under Goztepe Training and Research Hospital's Ethics Committee approval (Decision \#: 48/G; June 2008). Thirty-three patients underwent surgery at the Goztepe Training and Research Hospital Neurosurgery Clinic between 2006 and 2008. The pathological and clinical characteristics of the patients were recorded. DNA isolation of tissue biopsy samples was performed at the Yeditepe University Genetics and Bioengineering Department Molecular Diagnostic Laboratory. Isolated DNA samples under UV light are presented in Figure 1. A control group of 33 healthy patients were also included in the study. DNA was isolated from meningioma tissues in the patients, and from blood in the control group.
Isolated DNA samples were amplified by Polymerase Chain Reaction (PCR) with primers targeting the MMP-1 gene promoter region. Genotyping was performed by incubation with the Alul restriction enzyme and subsequent agarose gel electrophoresis. The bands were visualized by ethidium bromide under UV light. The Qiagen QIAamp DNA Mini Kit (cat no: 51306) was used for genomic DNA isolation from the biopsy tissue.

\section{PCR Amplification}

The MMP-1 promoter region of isolated DNA samples was targeted for amplification using a thermal cycling device. The amplification also served as a site-directed mutagenesis step in which a guanine was introduced by the reverse primer. Mutagenesis of the amplicon is required to generate a restriction site that is recognized and cut by the Alul enzyme in subsequent RFLP analysis.

Forward Primer: TCACTTTTAAAACATAGTCTATGTCA (27 bp)

Reverse Primer: TCTTGGATTGATTTGAGATAAGTCATAGC (29 bp)

\section{Restriction Fragment Length Polymorphism (RFLP)}

At this stage, PCR products were treated with the Alul restriction enzyme. Amplicons containing the directed mutation are treated with Alul enzyme, and blind cuts are performed as indicated below. Genotyping with the Alul enzyme is dependent on the presence or absence of the guanine base insertion within the amplicons obtained. Amplified fragments containing the guanine insertion do not contain an Alul restriction site and result in a single full-sized product. However, in the case that the insertion is absent, Alul will cut the amplicon into two fragments of $262 \mathrm{bp}$ and $28 \mathrm{bp}$ in length. An agarose gel containing DNA obtained from tissue biopsy samples is presented in Figure 2.
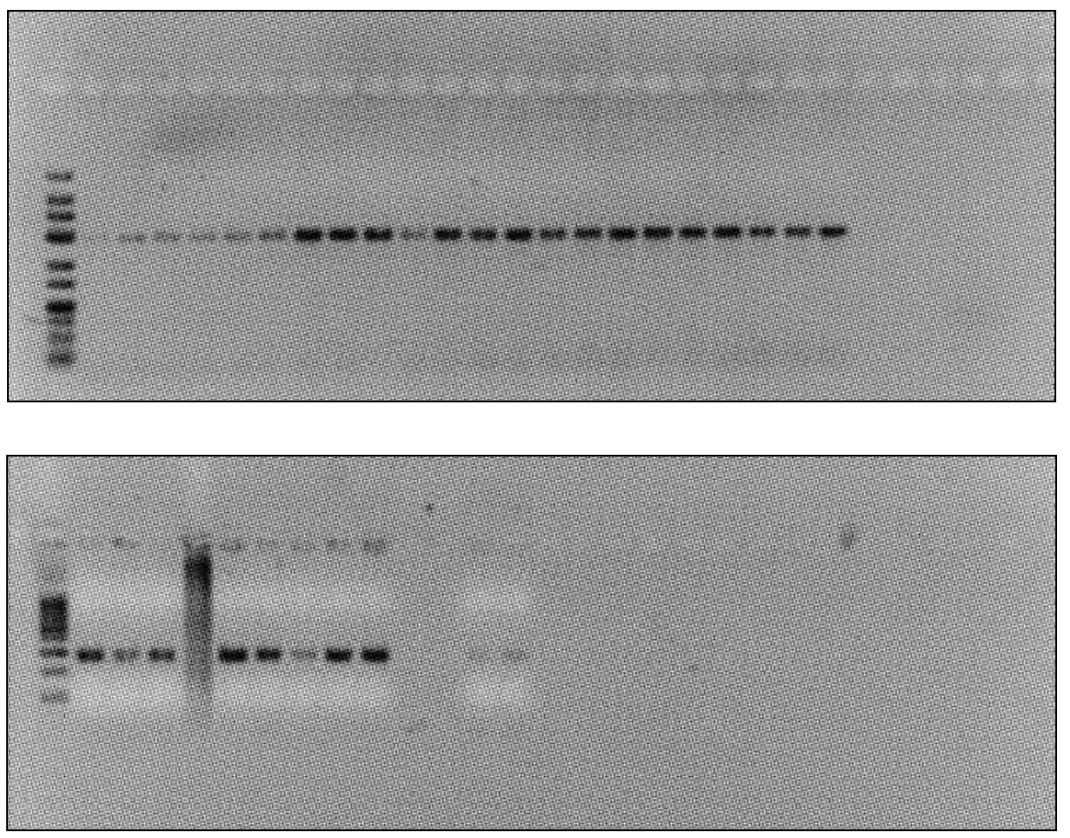

Figure 1: Images of isolated DNA samples under UV light after gel electrophoresis for ten minutes in a $2 \%$ agarose gel at $100 \mathrm{~mA}, 150 \mathrm{~W}$.

Figure 2: Agarose gel containing DNA from 33 patient tissue biopsy samples. The DNA was isolated from tissue biopsy samples and amplified by PCR after treatment with the Alul restriction enzyme. 


\section{Statistical Analyses}

Statistical analyses were performed with NCSS 2007 and PASS 2008 Statistical Software (Utah, USA). To compare quantitative data, we used a one-way ANOVA test and descriptive statistical methods, including average, standard deviation and frequency. Chi-squared tests (with both a single square and multiple squares) were performed to compare the qualitative data. The results were evaluated by a $95 \%$ confidence interval and a significance level of $p<0.05$.

\section{RESULTS}

The study was performed between 2006 and 2008, with a total of 33 meningioma patients ranging in age from 9 to 83 years. Of these, 20 patients were females $(60.6 \%)$, and 13 were males (39.4\%). The mean age of the patients is $52.63 \pm 16.23$. The subtypes encountered included transitional (57.6\%), meningothelial (18.2\%), atypical (12.1\%), fibrous (6.1\%) and psammomatous (6.1\%) meningiomas. According to the WHO classification of meningiomas, $87.9 \%$ of the affected patients were grade 1 , and $12.1 \%$ were grade 2 . Patients presented with headaches $(84.8 \%)$, imbalance (21.2\%), seizures (15.2\%), hearing loss (12.1\%), vision loss (6.1\%) and anosmia (6.1\%).

In total, $72.7 \%$ of the meningioma patients $(n=24)$ had at least one copy of the insertion ( $2 \mathrm{G} / 1 \mathrm{G}$ or $2 \mathrm{G} / 2 \mathrm{G}$ genotypes) and $27.3 \%(n=9)$ did not $(1 \mathrm{G} / 1 \mathrm{G})$. There were more meningioma patients with at least one copy of the insertion than patients with no insertion. In meningioma patients, the set of $2 \mathrm{G} / 1 \mathrm{G}+2 \mathrm{G} / 2 \mathrm{G}$ genotypes were significantly higher than the $1 \mathrm{G} / 1 \mathrm{G}$ genotype, and this difference was significantly different $(p<0.01)$ (Table I). The expected frequency of the $2 \mathrm{G} / 1 \mathrm{G}+2 \mathrm{G} / 2 \mathrm{G}$ genotypes to the $1 \mathrm{G} / 1 \mathrm{G}$ genotype was the same but comparing expected frequencies of genotypes with the frequencies in the meningioma patients showed that there was statistically significant difference between these groups and there were more $2 \mathrm{G} / 1 \mathrm{G}+2 \mathrm{G} / 2 \mathrm{G}$ occurrences in the meningioma group (P value 0.009) (Table II). Comparing the $2 \mathrm{G} / 1 \mathrm{G}+2 \mathrm{G} / 2 \mathrm{G}$ genotype distribution of the meningioma group to the control group showed that the $2 \mathrm{G} / 1 \mathrm{G}+2 \mathrm{G} / 2 \mathrm{G}$ genotype distribution was $72.7 \%$ in both the meningioma and control group. Therefore, there was no significant difference between the groups ( $p>0.05$ ) (Table III). Similarly, there was no significant difference between distributions of age and gender within the genotype groups.

\section{DISCUSSION}

A total of 26 consecutive members of the MMP family have been identified so far in the relevant literature. These enzymes have been classified by substrate and structural properties. Tumor cells break down important structural components of the extracellular matrix and prepare the environment for neovascularization. In this way, they ensure a path of travel within the affected tissue. The tumor cells are then able to both metastasize and grow further $(14,17,19)$. MMPs have an important role at this stage of tumor progression due to their collagen breakdown, which is a fundamental structure within the extracellular matrix $(4,5,7)$. The matrix metalloproteinase
(MMP) enzyme family is active in invasion and progression of many tumors by their degradation of the extracellular matrix $(24,28)$. Matrix metalloproteinase-1 (MMP-1) is also known as collagenase-1. MMP-1 is a zinc-dependent endopeptidase $(17,19,33)$ that is responsible for the breakdown of many proteins and collagens. MMP- 1 was considered to be less active than MMP-2 and MMP-9 in human brain tumors because no collagen is present in brain tissue $(6,20,29)$. However, studies have shown that such hypotheses are not accurate and suggest that the amount of MMP-1 in a tumor is closely related with its tumor grade and invasiveness (13).

MMP-1 is included in the interstitial collagenase group and breaks down stromal collagens and is located on chromosome 11 along with MMP-3. MMP-1 stimulates synthesis of other enzymes, such as MMP-3, MMP-1 and MMP-9 (9). Although these two enzymes have been identified in various tumor cells, they are also found in various normal cells, including epithelium cells, endothelium cells and macrophages (32). A single nucleotide polymorphism (SNP) in the promoter region of these enzymes affects their expression levels.

MMP-1 gene expression is controlled by activator protein-1 (AP-1) bound to regions in the MMP-1 promoter and mitogen-

Table I: Table Showing the Number of Meningioma Patients with at Least One Copy of the Insertion (2G/1G or $2 \mathrm{G} / 2 \mathrm{G}$ Genotypes) and Patients with No Insertion

\begin{tabular}{|l|c|c|c|}
\hline Genotype & $n$ & $\%$ & $p$ \\
\hline $2 G / 1 G+2 G / 2 G$ & 24 & 72.7 & $p<0.01$ \\
$1 G / 1 G$ & 9 & 27.3 &
\end{tabular}

$p<0.01$ means that the difference between these groups is statistically significant.

Table Il: Table Showing the Number of Meningioma Patients with at Least One Copy of the Insertion (2G/1G or 2G/2G Genotypes) and Patients with no Insertion, and Comparing These Numbers with Expected Frequencies of These Genotypes in the Population

\begin{tabular}{|l|c|c|c|}
\multirow{2}{*}{ Genotype } & $\begin{array}{c}\text { Frequency } \\
\text { observed }\end{array}$ & $\begin{array}{c}\text { Frequency } \\
\text { expected }\end{array}$ & \multicolumn{1}{|c}{} \\
\cline { 2 - 4 } & $\mathbf{n}(\%)$ & $\mathbf{n}(\%)$ & $\mathbf{p}$ \\
\hline \multirow{2}{*}{$\mathrm{G} / 1 \mathrm{G}+2 \mathrm{G} / 2 \mathrm{G}$} & $24(\% 72.7)$ & $16.5(\% 50,0)$ & $0.009^{* *}$ \\
\hline $1 \mathrm{G} / 1 \mathrm{G}$ & $9(\% 27.3)$ & $16.5(\% 50,0)$ &
\end{tabular}

The $p$ value of $0.009^{* *}$ means that the difference between these groups is statistically significant.

Table III: Table Comparing 2G/1G + 2G/2G and 1G/1G Distributions between the Meningioma and Control Groups

\begin{tabular}{|l|c|c|c|}
\multirow{2}{*}{ Genotype } & $\begin{array}{c}\text { Meningioma } \\
(\mathbf{n}: 33)\end{array}$ & $\begin{array}{c}\text { Control group } \\
(\mathrm{n}: 33)\end{array}$ & \multicolumn{1}{|c}{} \\
\cline { 2 - 4 } $2 \mathrm{n} / 1 \mathrm{G}+2 \mathrm{G} / 2 \mathrm{G}$ & $24(\% 72.7)$ & $24(\% 72.7)$ & $0.009^{* *}$ \\
\hline $1 G / 1 G$ & $9(\% 27.3)$ & $9(\% 27.3)$ & \\
\hline
\end{tabular}

There was no statistical difference between the groups $(p>0.05)$. 
activated kinase through polyomavirus-enhancing activity-3 (PEA-3/ETS) $(22,31)$. A new ETS-binding site is created by a guanine insertion in the MMP-1 gene promoter region at bp position 1607, thus enhancing the transcriptional activity of the MMP-1 gene. The presence of this guanine insertion is also correlated with the incidence and progression of several cancers (21).

The MMP-1 SNP is located at bp position 1607. Insertion of a guanine base at this position creates a binding site for members of the EST transcription factor family, which results in further MMP-1 expression $(21,22)$. While MMP-1 expression is increased depending on it, degradation of the extracellular matrix gradually increases depending on the level of MMP1 (31). Th polymorphism within the MMP-1 promoter region therefore has an important role in tumor invasion, metastasis and angiogenesis $(21,25)$. Highly invasive melanoma cells (34) as well as other cancer types such as lung and renal cell carcinoma, have been shown to contain the additional guanine in the MMP-1 promoter region.

PCR-based studies performed on glial tumors of different grades have shown that MMP-1 expression was greater in high-grade glial tumors (26). MMP-1 expression was found to be significantly higher in glioblastoma samples than in normal samples with the $2 \mathrm{G} / 2 \mathrm{G}$ genotype (11). Similarly, studies on astrocytomas reveal a significant increase when this region is deleted, as tumor grade is increased. The MMP-1 promoter polymorphism was found to be significant in astrocytoma development $(9,30)$.

In the single study performed on pituitary adenomas by Altas et al. in 2010, the $1 G / 2 \mathrm{G}$ and $2 \mathrm{G} / 2 \mathrm{G}$ distributions were significantly higher in invasive adenomas than in benign pituitary adenomas (1). The deletion in the MMP-1 promoter region was found in both glial tumors and pituitary adenomas, which are high-grade invasive tumors.

Currently, no studies in the literature research the relationship between the single nucleotide polymorphism of the matrix metalloproteinase-1 promoter region and tumor invasion. Microscopic invasion and infiltration of tumor cells have important roles in the recurrence of meningiomas $(8,12,15)$. The studies on tumor invasion and recurrence are focused on MMP-2 and MMP-9. MMP-2 expression is particularly observed in grade 2 and 3 meningiomas (16). There is a clear relationship between MMP-2 expression and tumor recurrence in meningiomas. MMP-2 and MMP-9 expression is associated with histologic malignancy. Therefore, the expression of these enzymes in anaplastic and atypical meningiomas is higher, which contributes to the invasive character of grade 2 and 3 meningiomas (30). However, its relation to MMP-9 expression is unclear. MMP-9 expression helps meningioma cells infiltrate the dura (12). Invasion of the normal arachnoid membrane adjacent to benign meningioma cells is highly important for meningioma recurrence. Invasion of the arachnoid membrane is one of the risk factors for recurrence that may then lead to an osseous invasion $(3,12)$.
In our study on the polymorphism of the MMP-1 promoter region in meningioma patients, $27.3 \%$ of patients were $1 \mathrm{G} / 1 \mathrm{G}$, $42.4 \%$ were $1 \mathrm{G} / 2 \mathrm{G}$ and $30.3 \%$ were $2 \mathrm{G} / 2 \mathrm{G}$. In total, the fraction of patients that exhibited at least one insertion was $72.7 \%$, and $27.3 \%$ of patients had no insertion. The expected frequency of patients with at least one copy of the insertion (2G/1G or $2 \mathrm{G} / 2 \mathrm{G}$ genotypes) and patients with no insertion should be equal. Regarding this similarity, there was a statistically significant larger number of $2 \mathrm{G} / 1 \mathrm{G}$ or $2 \mathrm{G} / 2 \mathrm{G}$ genotypes in meningioma group. However, comparing $2 \mathrm{G} / 1 \mathrm{G}+2 \mathrm{G} / 2 \mathrm{G}$ and $1 \mathrm{G} / 1 \mathrm{G}$ distributions between the meningioma and control groups showed that there was no statistically significant difference between these groups. This may be due to selection of control group or no effect of copy of insertion on tumorigenesis. The hypothesis was that copy of insertion has an influence on transcription meningioma tumorigenesis. There were significant differences when genotypically comparing recurrence patients. The presence of a guanine insertion was not found to be significantly correlated with recurrence in this study. With respect to progression, several patients had atypical meningioma, and thus it was not possible to establish a significant relationship between tumor progression and the malignancy grade of the tumor. As stated in the literature, high-grade tumors exhibit the greatest frequency of insertion. Similarly, an insertion is expected to be higher in grade 2 and 3 meningiomas. Furthermore, considering the fact that recurrence rate is closely related with tumor grade, a connection can be made between guanine insertion, tumor grade and recurrence rates in tumors with higher malignancy.

There is an insufficient number of studies in the literature that investigate the polymorphism of the MMP-1 gene promoter region in brain tumors. Therefore, additional studies should address the progression to malignancy in meningiomas. The effect of the MMP-1 promoter polymorphism will become clearer through these types of studies, and such studies will help us understand the relationship between the guanine insertion and tumorigenesis and tumor progression.

This study is generally focused on grade 1 (benign) meningioma patients. The fraction of grade 2 (atypical) meningioma patients in our study is only $12 \%$. In the literature, the insertion in the promoter region is reported to be significantly greater in high-grade tumors. To provide further information on meningiomas, there should be more atypical patients and particularly patients with malignant meningiomas. Therefore, atypical patients with malignant meningioma should be included in the study and the genotype determined using our method.

After inclusion of atypical patients with malignant meningioma, long-term follow-up of the patients should be performed and patients with reported recurrence and those that die during follow-up should be assessed. We can thus elucidate the progression and recurrence effects of the polymorphism on the MMP-1 gene promoter region, which is observed especially in metastatic cases and also in high-grade glial tumors and meningioma patients. The meningioma grade and geno- 
type of exitus patients can also be compared with the goal of ascertaining the effects of an insertion on prognosis.

\section{CONCLUSION}

We found that a polymorphism on the matrix metalloproteinase-1 gene promoter region does not have an effect on formation, growth and progression of meningioma. To obtain further information on the subject, the number of atypical and malignant cases should be increased, long-term followup should be performed and cases that die or develop recurrence should be evaluated separately.

\section{REFERENCES}

1. Altas M, Bayrak OF, Ayan E, Bolukbasi FH, Silav G, Coskun KK, Culha M, Sahin F, Sevli S, Elmac I: The effect of polymorphisms in the promoter region of the MMP-1 gene on the occurrence and invasiveness of hypophyseal adenoma. Acta Neurochir 152: 1611-1617, 2010

2. Ayerbe J, Lobato RD, de la Cruz J, Alday R, Rivas JJ, Gomez PA, Cabrera A: Risk factors predicting recurrence in patients operated on for intracranial meningioma. A multivariate analysis. Acta Neurochir (Wien) 141:921-932, 1999

3. Beliveau R, Delbecchi L, Beaulieu E, Mousseau N, Kachra Z, Berthelet F, Moumdjian R, Del Maestro R: Expression of matrix metalloproteinases and their inhibitors in human brain tumors. Ann NY Acad Sci 886: 236-239, 1999

4. Curran S, Murray Gl: Matrix metalloproteinases in tumour invasion and metastasis. J Pathol 189:300-308, 1999

5. Egeblad $M$, Werb $Z$ : New functions for the matrix metalloproteinases in cancer progression. Nat Rev Cancer 2:161-174, 2002

6. Fillmore $\mathrm{HL}$, Van Meter $\mathrm{T}$, Broaddus WC: Membrane type metalloproteinases (MT-MMPs): Expression and function during glioma invasion. J Neurooncol 53:187-202, 2001

7. Johnsen M, Lund LR, Romer J, Almholt K, Dano K: Cancer invasion and tissue remodeling: Common themes in proteolytic matrix degradation. Curr Opin Cell Biol 10: 667-671, 1998

8. Kirches E, Grunewald J, von Bossanyi P, Szibor R, Plate I, Kruger S, Warich Kirches M, Dietzmann K: Expression of matrix metalloproteinases in a series of 12 meningiomas. Clin Neuropathol 20: 26-30, 2001

9. Lu Z, Cao Y, Wang Y, Zhang Q, Zhang X, Wang S, Li Y, Xie H, Jiao $\mathrm{B}$, Zhang J: Polymorphisms in the matrix metalloproteinase-1, 3 , and 9 promoters and susceptibility to adult astrocytoma in Northern China. J Neurooncol 85: 65-73, 2007

10. Malmer B, Gronberg H, Bergenheim AT, Lenner $P$, Henriksson R: Familial aggregation of astrocytoma in Northern Sweden: An epidemiological cohort study. Int J Cancer 81:366-370, 1999

11. McCready J, Broaddus WC, Sykes V, Fillmore H: Association of a single nucleotide polymorphism in the matrix metalloproteinase-1 promoter with glioblastoma. Int J Cancer 117: 781-785, 2005
12. Mizoue $T$, Kawamoto $H$, Arita $K$, Tominaga A, Kurisu $K$ : Secretion of matrix metalloproteinase- 9 and tissue inhibitor of metalloproteinase- 1 by meningiomas detected by cell immunoblot analysis. Acta Neurochir (Wien) 141: 481-486, 1999

13. Nakagawa T, Kubota T, Kabuto Masanori, Sato K, Kawano $H$, Hayakawa T, Okada Y: Production of matrix metallooproteinases and tissue inhibitor of metalloproteinases- 1 by human brain tumors. J Neurosurg 81:69-77, 1994

14. Noe V, Fingleton B, Jacobs $K$, Crawford HC, Vermeulen $S$, Steelant W, Bruyneel E, Matrisian LM, Mareel M: Rlease of an inasion promotor E-cadrein fragment by matrilysin and stromalysin-1. J Cell Sci 114: 111-118, 2001

15. Nordqvist AC, Smurawa $H$, Mathiesen T: Expression of matrix metalloproteinases 2 and 9 in meningiomas associated with different degrees of brain invasiveness and edema. J Neurosurg 95: 839-844, 2001

16. Okuducu AF, Zils $U$, Michaelis SAM, Michaelides $S$, von Deimling A: Ets-1 is up-regulated together with its target gene products matrix metalloproteinase-2 and matrix metalloproteinase- 9 in atypical and anaplastic meningiomas. Histopathology 48:836-845, 2006

17. Parson SL, Watson SA, Brown PD, Collins HM, Steele RJ: Matrix metalloproteinases. Br J Surg 84:160-166, 1997

18. Perry A, Stafford SL, Scheithauer BW, Lohse CM, Wollan PC: "Malignancy" in meningiomas: A clinicopathological study of 116 patients with grading implications. Cancer 85 : 2046-2056, 1999

19. Powell WC, Fingleton $B$, Wilson $C L$, Boothby $M$, Matrisian LM: The metalloproteinase matrilysin proteolytically generates active soluable Fas ligand and potentiates epitheliak cell apoptosis. Curr Biol 9:1441-1447, 1999

20. Rooprai HK, Van Meter T, Rucklidge GJ, Hudson L, Everall IP, Pilkington GJ: Comparative analysis of matrix metalloproteinases by immunocytochemistry, immunohistochemistry and ymography in human primary brain tumors. International J Oncol 13:1153-1157, 1998

21. Rutter J, Mitchell T, Buttice G, Meyers J, Gusella J, Ozelius L, Brinckerhoff CE: A single nucleotide polymorphism in the matrix metalloproteinase-1 promoter creates an Ets binding site and augments transcription. Cancer Res 58:5321-5325, 1998

22. Sharrocks AD, Brown AL, Ling Y, Yates PR: The ETS domain transcription factor family. Int J Biochem Cell Biol 29: 1371-1387, 1997

23. Simpson $D$ : The recurrence of intracranial meningiomas after surgical treatment. J Neurol Neurosurg psychiatry 20:22-39, 1957

24. Stamenkovic I: Extracellular matrix remodelling: The role of matrix metalloproteinases. J Pathol 200:448-464, 2003

25. Sternlicht M, Werb Z: How matrix metalloproteinases regulate cell behavior. Annu Rev Cell Dev Biol 17: 463-516, 2001 
26. Stojic J, Hagemann C, Haas S, Herbold C, Kühnel S, Gerngras $\mathrm{S}$, Roggendorf W, Roosen $\mathrm{K}$, Vince GH: Expression of matrix metalloproteinases MMP-1, MMP-11 and MMP-19 is correlated with the WHO-grading of human malignant gliomas. Neurosci Res 60:40-49, 2008

27. Takahashi JA, Ueba T, Hashimoto N, Nakashima Y, Katsuki $\mathrm{N}$ : The combination of mitotic and $\mathrm{Ki}-67$ indices as a useful method for predicting short-term recurrence of meningiomas. Surg Neurol 61:149-156, 2004

28. Uhm JH, Dooley NP, Villemure JG, Yong VW: Mechanisms of glioma invasion: Role of matrix-metalloproteinases. Can J Neurol Sci 24 :3-15, 1997

29. Van Meter TE, Rooprai HK, Kibble MM, Fillmore HL, Broaddus WC, Pilkington GJ:The role of matrix metalloproteinase genes in glioma invasion: Co-dependent and interactive proteolysis. J Neurooncol 53:213-235, 2001
30. von Randow AJ, Schindler S, Tews DS: Expression of extracellular matrix-degrading proteins in classic, atypical, and anaplastic meningiomas. Pathol Res Pract 202:365-372, 2006

31. Westermarck J, Seth A, Kahari VM: Differential regulation of interstitial collagenase (MMP-1) gene expression by ETS transcription factors. Oncogene 14:2651-2660, 1997

32. Wilhelm SM, Eisen AZ, Teter M, Clark SD, Kronberger A, Goldberg G: Human fibroblast collagenase: Glycosylation and tissue-specific levels of enzyme synthesis. Proc Natl Acad Sci USA 83:3756-3760, 1986

33. Woessner JF Jr: Matrix metalloproteinase and their inhibitors in connective tissue remodeling. FASEB J 5: 2145-2154, 1991

34. Ye S, Dhillon S, Turner S, Bateman A, Theaker J, Pickering R, Day I, Howell M: Invasiveness of cutaneous malignant melanoma is influenced by matrix metalloproteinase 1 gene polymorphism. Cancer Res 61:1296-1298, 2001 